\title{
Optimalisasi Psikologi Perkembangan Anak dalam Lingkungan Keluarga
}

\author{
Alfiyanti Nurkhasyanah \\ Universitas Islam Negeri Sunan Kalijaga \\ Email: alfiyantinurkhasyanah@gmail.com
}

Naskah diterima: 17 Juni 2020, direvisi: 07 September 2020, diterbitkan: 23 September 2020

\begin{abstract}
Abstrak
Psikologi perkembangan anak menjadi salah satu persoalan yang banyak dialami terutama dalam lingkungan keluarga. Kesulitan dalam mendidik karena tidak sesuai dengan harapan menjadikan anak tidak tumbuh maupun berkembang sesuai usianya. Artikel ini menggunakan jenis penelitian kepustakaan (library research). Penelitian ini dilakukan untuk menghimpun serta menganalisa data yang bersumber dari buku, majalah, koran, dan karya ilmiah lainnya. Penelitian kepustakaan menggunakan pendekatan yang bersifat kualitatif. Berdasarkan hasil berbagai penelitian disajikan untuk membahas Persoalan yang saat ini dihadapi yakni tidak semua lingkungan keluarga dapat memenuhi harapan dan kebutuhan anak terutama dalam psikologi perkembangannya. Lingkungan keluarga yang berperan sebagai pendidik yang baik dan memenuhi standar menjadi sebuah keseharusan bagi orang tua. Jika tidak, maka psikologi perkembangan anaklah yang menjadi taruhannya, karena orangtua dan anak saling bersinergi untuk menunjang masa depannya. Lingkungan keluarga terutama orang tua merupakan pendidikan pertama bagi psikologi perkembangan anak. Proses perkembangan anak dalam berbagai macam aspek seperti bahasa, fisik-motorik, emosi harus mendapatkan dukungan penting dalam lingkungan keluarga karena dapat menjadikan modal dalam kehidupan anak di masa yang akan datang.
\end{abstract}

Kata kunci: psikologi, perkembangan anak, keluarga

\begin{abstract}
The psychology of child development is one of the most common problems, especially in the family environment. Difficulty in educating because it is not in accordance with expectations makes children not grow or develop according to their age. This article uses a type of library research. This research was conducted to collect and analyze data from books, magazines, newspapers, and other scientific
\end{abstract}


works. Library research uses a qualitative approach. Based on the results of various studies presented to discuss the problem currently faced, not all family environments can meet the hopes and needs of children, especially in their developmental psychology. A family environment that acts as a good educator and meets standards becomes a necessity for parents. If not, then the child's developmental psychology is at stake, because parents and children work together to support their future. Family environment, especially parents, is the first education for child development psychology. The process of child development in various aspects such as language, physical-motor, emotional must receive important support in the family environment because it can be used as capital in children's lives in the future.

Keywords: psychology, development children, family

\section{Pendahuluan}

Psikologi sebagai sebuah disiplin ilmu sangat dibutuhkan oleh dunia pendidikan. Psikologi pendidikan dapat dikatakan sebagai penunjang untuk pengembangan potensi manusia melalui belajar dan pembelajaran (Idad, 2016). Hal ini psikologi diartikan sebagai proses fase perkembangan yang berpengaruh pada kehidupan manusia selanjutnya. Perkembangan dapat didefinisikan sebagai perubahan fisik, struktur syaraf, prilaku dan sifat yang terbentuk secara teratur dan berlangsung terus (Paul \& Dkk, 1988).

Istilah perkembangan berarti serangkaian perubahan progresif yang terjadi sebagai akibat dari proses kematangan dan pengalaman. Seperti yang dikatakan oleh Van Den Daele dalam buku (Hurlock, 1980) menyatakan "perkembangan merupakan perubahan secara kualitatif'. Bahwasannya perkembangan bukan sekedar penambahan beberapa sentimeter pada tinggi badan seseorang atau peningkatan kemampuan seseorang, melainkan suatu proses integrasi dari banyak struktur dan fungsi yang kompleks. Dalam hal ini perkembangan berlangsung seumur hidup, sedangkan pertumbuhan mengalami batasan tertentu.

Anak-anak usia dini berada pada masa emas (Golden Age) dimana pertumbuhan dan perkembangan anak usia dini sedang terjadi lonjakan yang luar biasa bahkan jarang terjadi pada periode berikutnya. Pada masa ini pertumbuhan dan perkembangan anak usia dini sedang berlangsung sangat pesat. Menurut (UU Sisdiknas Tahun, 2013) Undang-Undang Nomor 20 Tahun 2003 pasal 1 ayat 14 tentang Sistem Pendidikan Nasional menyatakan bahwa Pendidikan Anak Usia Dini adalah suatu upaya pembinaan yang ditujukan kepada anak sejak lahir sampai dengan usia enam tahun yang dilakukan melalui pemberian 
rangsangan pendidikan untuk membantu pertumbuhan dan perkembangan jasmani dan rohani agar anak memiliki kesiapan dalam memasuki pendidikan lebih lanjut. Pendidikan Anak Usia Dini dalam Undang-Undang Sisdiknas Nomor 20 Tahun 2003 pasal 28 ayat 3 dinyatakan sebagai jalur pendidikan formal berbentuk Taman Kanak-Kanak (TK), Raudhatul Athfal (RA) atau bentuk lain yang sederajat.

Akhir-akhir ini banyak anak yang psikologi perkembangannya tidak sesuai dengan usianya, berdasarkana fakta dan fenomena saat ini di jaman yang disebut-sebut era revolusi industry 4.0 banyak sekali anak usia dini yang tumbuh tidak sesuai perkembangannya dikarenakan kondisi lingkungan yang memberikan pengaruh negatif. Salah satu yang memberikan pengaruh negatif adalah lingkungan anak baik lingkungan keluarga maupun lingkungan bermain anak. Keluarga adalah lingkungan pertama bagi anak, dalam lingkungan keluarga anak pertama kali memperoleh pengaruh, maka sudah seharusnya keluarga memperhatikan psikologi perkembangan anak. Pendidikan keluarga merupakan lembaga pendidikan pertama, tempat pertama kalinya anak mendapatkan pendidikan serta bimbingan dari orang tua atau anggota dalam keluarga lainnya.

Dalam keluarga seharusnya anak memiliki kenyamanan dalam melakukan berbagai macam aktivitas. Aktivitas tersebutlah yang dapat berperan terhadap psikologi perkembangan anak nantinya. Setiap orang tua mempunyai pola asuh yang berbeda pengaplikasiannya kepada anak, dan inilah yang sangat mempengaruhi psikologi perkembangan. Dengan dinyatakannya pandemi oleh WHO dan pemerintah mengkampayekan untuk Work From Home atau bekerja dirumah saja, seharusnya keluarga memiliki Quality Time yang tidak seharusnya disia-siakan. Dengan bekerja di dalam rumah keluarga memiliki kesempatan untuk mengawasi dan mengoptimalkan psikologi perkembangan anak secara optimal.

Namun, kenyataannya dimasa pandemi ini peran keluarga kurang di optimalkan secara baik. Dengan adanya bekerja dirumah dan belajar dirumah malah justru kegiatan yang dilakukan lebih kepada fokus pada penggunaan teknologi (Ulfa, 2020) sehingga aspek perkembangan lainnya tidak diasah dengan baik. Sehingga, dalam penelitian ini peneliti mengambil judul optimalisasi psikologi perkembangan anak dalam lingkungan keluarga. Yang mana keluarga berperan penting dalam psikologi perkembangannya. 


\section{Metodologi}

Jenis penelitian ini adalah penelitian kepustakaan (library research), penelitian kepustakaan yang dimaksud ialah suatu penelitian yang dilakukan untuk menghimpun serta menganalisa data yang bersumber dari buku, majalah, koran, dan karya ilmiah lainnya. Penelitian kepustakaan menggunakan pendekatan yang bersifat kualitatif, karena kualitatif berpusat pada teori berdasarkan konsep yang akan dibahas. (Sugiyono, 2013) Penelitian kepustakaan memiliki kegunaan untuk memecahkan masalah yang belum jelas,dinamis, komplek, holistik, dan memiliki makna dari sumber yang tertulis (Khoirunnisa, 2018). Penelitian ini menganalisis tentang "Optimalisasi Psikologi Perkembangan Anak dalam Lingkungan Keluarga”.

\section{Hasil dan Diskusi}

Hasil dan diskusi yang dapat dianalisa penulis memiliki beberapa kajian pembahasan yaitu psikologi perkembangan, keluaraga serta optimalisasi psikologi perkembangan anak dalam keluarga

\section{A. Psikologi Perkembangan}

Secara etimologi (Idad, 2016) psikologi dapat diartikan sebagai pengetahuan tentang jiwa atau ilmu jiwa. Sedangkan dalam buku (H.B \& A.C, 1958) psikologi merupakan cabang ilmu penegtahuan yang membahas perilaku, tindakan, atau proses mental dan pikiran, diri atau kepribadian yang terkait dengan proses mental. Psikologi aspek yang menentukan sebarapa kuat sesorang dalam menjalani kehidupan pribadinya. Untuk mendukung psikologi menjadi baik seseorang perlu menyuplai jiwanya untuk berperilaku baik. Psikologi itu sendiri memiliki keterkaitan antara indiviu satu dengan yang lainnya, dari keterkaitan itulah timbulnya interaksi antar sesama yang menjadikan seseorang bisa melakukan perilaku atau berperilaku.Dari beberapa pendapat yang mengemukakan tentang defisini psikologi, penulis berpendapat bahwa psikologi adalah ilmu pengetahuan yang mengkaji serta meneliti proses mental dan perilaku pada seseorang.

Develompent merupakan Bahasa Inggris dari perkembangan. Pendapat yang dikemukakan oleh Santrock (Santrock, 2011) mengartikan bahwa perkembangan merupakan pola perubahan yang dimulai sejak masa konsepsi dan berlanjut sampai sepanjang hayat. Sebuah istilah perkembangan berorientasi pada proses mental sedangkan pertumbuhan berorientasi 
pada peningkatan ukuran dan sruktur. Yang yang bersifat fungsional merupakan perkembangan. Sedangkan yang bersifat biologis merupakan pertumbuhan.

Psikologi perkembangan anak usia dini memiliki waktu yang renta dari setiap perkembangannya. Istilah psikologi perkembangan diartikan sebagai perubahan yang tidak bersifat kuantitatif melainkan kualitatif. Golden Age atau biasa dikenal usia emas anak usia dini memiliki lonjakan perkembangan yang signifikan dan bias saja tidak mengalami pengulangan perkembangan diperiode usia berikutnya. Fokus utama terhadap psikologi perkembangan anak usia dini yakni menerapkan prinsip-prinsip sebagai landasan tumbuh dan berkembangnya anak. Namun dalam hal ini mengamati tingkah polah anak merupakan sesuatu yang menyenangkan. Tapi apakah saat kita mengamati tingkah dan polah anak sudah sesuai dengan ketentuan perkembangan yang ada. Bisa jadi perkembangan yang terjadi pada anak belum maksimal sesuai dengan ketentuan. Contoh sederhana dalam kegiatan keseharian anak yaitu seperti bagaimana kemajuan dalam ketrampilam motorik mempengaruhi kemampuan anak dalam bersosialisasi. Kemudian apakah perkembangan yang terjadi pada anak semata-mata dipengaruhi oleh faktor keturunan ataau lebih banyak ditentukan oleh faktor lingkungan.

\section{B. Keluarga}

Tia Novela dalam jurnalnya (Novela, 2019) menyatakan keluarga adalah suatu ikatan yang dibentuk dari perkawinan antara jenis laki-laki dan perempuan yang disahkan oleh pemerintah sehingga dapat menjalani kehidupan bersama, dengan tujuan yang sama dalam membina sebuah rumah tangga untuk mencapai keluarga yang sakinah dalam lindungan dan di rida Allah SWT.

Keluarga adalah individu yang berinteraksi dengan subsistem yang berbeda yaitu bersifat dyadic yang melibatkan dua orang dan polyadic yang melibatkan lebih dari dua orang (Santrock, 2011). Subsistem ini mempunyai pengaruh langsung maupun tidak langsung terhadap satu sama lainnya. Hubungan pengaruh yang positif bisa berpengaruh positif pada pengasuhan. Pengaruh terbesar yang memeberikan efek positif maupun negatif pada anak adalah keluarga. Kemampuan intelektual anak dominan diberikan pada rangsangan keluarga kepada anak. Pengaruh pembelajaran, rangsangan fisik, rangsangan akaemik dan pemberian pengalaman kepada anak usia sekolah memberikan makna yang baik terhadap IQ anak.

Psikologi perkembangan anak dalam keluarga dapat diberikan melalui pengawan intern maupun ektren (Hulukati, 2015). Pendapat lain mengemukakan terkait keluarga 
bahwasannya keluarga memiliki peran uatama dalam mengasuh anak (Effendi \& Dkk, 1995). Untuk meningkatkan kualitas sumber daya manusia yang unggul keluarga bertanggung jawab atas itu. Dari setiap definisi yang dipaparkan menunjukkan bahwa keluarga yang seharusnya menjadi penentu psikologi perkembangan anak. Pengasuhan yang tidak optimal membuat anak tidak memiliki tujuan arah untuk hidupnya.

\section{Optimalisasi Psikologi Perkembangan Anak dalam Keluarga}

Keluarga ialah gugus sub-sistem yang disebut dengan generasi, gender dan peran. Yang mana setip anggotanya merupakan partisipan dalam beberapa subsistem (Ayun, 2016). Dimasa pandemic ini berbagai cara orangtua mendidik anak agar psikologi perkembangannya tetap berkembang dengan baik, akan tetapi dari berbagai penelitian yang dianalisis dan diamati hampir 85\% mendidik anak agar psikologi perkembangannya tetap berkembang para orangtua menggunakan cara berdasarkan keinginan dan pengalam dulu saat mereka di didik oleh orangtuanya. Akan tetapi tidak semua anak dapat di didik dengan cara yang sama, karena setiap anak punya perbedaan masing-masing dalam tumbuh kembangnya. Masa depan anak tergantung dari pengalaman yang diterima oleh anak baik lingkungan sosial maupun keluarga, dimana pembentukan pribadi anak jika dilakukan sejak dini akan membantu mengoptimalkan pertumbuhan dan perkembangan di setiap fase yang dilaluinya.

Masa anak usia dini melewati banyak hal pada setiap tahap perkembangannya sehingga beberapa prilaku dapat mempengaruhinya. Pada umumnya prilaku anak yang terjadi paada masa ini akan berlalu dengan sendirinya dan faktor yang menjadi penentu psikologi perkembangan fisik maupun mental anak adalah peran orang tua (Gunadi, 2019).

Dalam psikologi perkembangan anak mencakup berbagai aspek. Secara global psikologi perkembangan anak mencangkup perkembangan fisik, sosial, emosi, dan kognitif. Di dalam Peraturan Menteri Pendidikan dan Kebudayaan Nomor 146 Tahun 2014 tentang Kurikulum 2013 Pendidikan Anak Usia Dini pada pasal 5 dinyatakan bahwa aspek-aspek pengembangan dalam kurikulum PAUD mencakup: nilai agama, nilai moral, fisik-motorik, kognitif, bahasa, sosial-emosional, dan seni.Psikologi perkembangan yang tengah dikemukakan oleh berbagai sumber memiliki berbagai manfaat dalam penerapannya. Lingkungan pertama kali mempengaruhi psikologi perkembangan anak adalah keluarga. Oleh karena itu, keluarga menjadi ruang lingkup pertama bagi anak untuk tumbuh dan 
berkembang memiliki kewajiban dalam mengoptimalkan psikologi perkembangan anak melalui berbagai aspek yang dikembangan dan sesuai dengan usia anak.

Usia nol sampai sembilan orang tua atau keluarga sebaiknya membimbing bayi dalam mengangkat kepala empat puluh lima derajat dan menggerakkan kepala ke kanan dan kekiri, melihat wajah orang, terkejut, tersenyum. Memperkenalkan berbagai suara dan warna yang mencolok, membolak balikkan badan, melatih memegang mainan dan seterusnya sesuai dengan usianya

Usia satu tahun memperhatikan perkembangan fisik anak usia satu tahun, keluarga menfasilitasi anak untuk mengembangkan kemampuan: a) motorik kasar: Berdiri tanpa berpegangan, membungkuk untuk mengambil mainan, berjalan mundur lima langkah, menaiki tangga, menumpuk dua-empat kubus, memasukkan kubus dalam kotak, memegang alat tulis walaupun belum tepat (mencoret-coret kertas), b) motorik halus: bertepuk tangan, berjalan dengan stabil, melambai, memegang alat ulis, menggelindingkan bola, belajar makan dan minum sendiri.

Usia dua tahun ketika anak mengalami transisi dari bayi ke anak dua tahun yang mandiri, perubahannya bisa saja membuat kita kewalahan, tetapi hasilnya mengagumkan. Anak usia dua tahun sering merasa frustasi pada saat mereka berusaha mandiri, tetapi tidak memenuhi kebutuhan dan keinginan mereka. Misalnya mereka bisa mengenakan pakaian sendiri dengan lengkap, tetapi mereka belum mempunyai kontrol motorik halus untuk mengancingkan, menarik resleting atau memasang gesper. Mereka mempunyai tenagaterbatas, tetapi menolak tidur siang. Mereka ingin mandiri, tetapi sering mengalami kesulitan berpisah dengan orang tua atau pengasuh. Mereka bertambah takut dengan gelap, monster dan lain-lain. Ditambah dengan tuntutan emosional latihan buang air sendiri dan kesemuanya itu muncul pada masa bergejolak ini.

Dalam mendorong perkembangan bahasa anak, keluarga seharusnya memfasilitasi anak untuk media untuk belajar anakseperti : a) buku, puzzle, gambar sederhana, b) bagaimana menikmati musik dan irama, bermain jari sederhana, c) kata-kata baru dan membentuk kalimat lengkap dan bertambah kompleks (perbendaharaan kata sekitar dua ratus kata) menggunakan kata sifat dan kata keterangan), d) mendengarkan cerita (jangka perhatian pendek), e) mengidentifikasi objek dalam gambar.

Dalam optimalisasi perkembangan fisik anak, keluarga sebaiknya mengembangkan kemampuan anak dalam: a) keterampilan motorik kasar: anak dapat menendang bola, naik 
turun tangga, dan dapat memakai topi dan sandal, b) keterampilan motorik halus: anak dapat mencoret-coret dengan spidol, meronce manik-manik besar, makan sendiri dengan sendok, mulai menuangkan jus dari teko kecil ke cangkir kecil.

Dalam optimalisasi perkembangan intelektual, keluarga seharusnya mendorong anak untuk belajar tentang: a) klasifikasi: dalam kategori luas, seperti kasar atau halus, besar atau kecil, b) bagian tubuh: dapat menyebutkan hidung, mata, mulut dan lain-lain, c) konsep waktu pendek seperti kemarin dan besok (tapi belum mengerti dengan nyata masa yang lebih panjang, seperti bulan, minggu), d) Bagaimana mengingat kejadian-kejadian pagi/dalam sehari, e) Bagaimana menikmati proses membuat hasta karya daripada tertarik pada hasilnya.

Dalam optimalisasi perkembangan sosial emosional anak, keluarga mendorong anak untuk belajar tentang: a) bermain interaktif tetapi masih cenderung bermain paralel disamping teman, b) bergiliran tetapi terkadang dengan kesulitan, c) bangga dengan ciptaan dan keberhasilan, d) macammacam perasaan dan sering menunjukkan tingkah laku agresif dan ketakutan bertambah.

Usia tiga tahun adalah usia yang menyenangkan, anak menjadi makhluk sosialtertarik berteman dengan anak-anak lain, mulai bisa berbagi dan bergiliran. anak belajar berpisah dari orang tua. Kegiatan kelompok kecil lebih efektif daripada kelompok besar. Keluarga harus harus berfokus pada bahasa, kegiatan, dan gerak. Memperhatikan bermain anak yang dilakukan oleh teman sebayanya diluar serta mengawasinya dengan hati-hati. Keterampilan motorik kasar berkembang dengan cepat. Anak usia tiga tahun perlu mengendarai mainan beroda, memanjat, melompat, berlari, menendang bola. Untuk kegiatan apapun, proses lebih penting daripada hasil jadinya.

Dalam optimalisasi perkembangan bahasa anak, keluarga sebaiknya mengembangkan bahasa anak dengan cara antara lain: a) menulis nama mereka sendiri (mungkin bisa menulis huruf pertama), b) pura-pura menulis (mencoret), c) duduk dan mendengarkan buku yang dibacakan dalam kelompok, d) berbicara didepan kelompok, e) melihat-lihat buku, f) bermain pantun dan lagu-lagu, g) bercerita untuk menyertai pekerjaan seni mereka, h) menggambar orang (mungkin tanpa anatomi terperinci seperti jari-jari).

Dalam optimalisasi perkembangan fisik anak, keluarga membimbing anak untuk melakukan kegiatan: a) keterampilan motorik kasar. Dapat berlari, melompat, memanjat, 
mengendarai sepeda, naik tangga dengan satu kaki tiap tangga, b) keterampilan motorik halus. Mereka dapat menggunakan kuas, krayon, spidol (dengan ujung besar), membuka resleting, menggambar lingkaran. Dalam optimalisasi perkembangan kognitif anak, keluarga membimbing anak untuk belajar: a) warna, bentuk, b) benda-benda yang serupa dan yang berbeda, c) hubungan spasial:atas/bawah, dekat/jauh, d) menghitung dari satu sampai dengan sepuluh.

Dalam optimalisasi perkembangan sosio emosional anak, keluarga mendorong anak untuk belajar: a) jauh dari rumah, b) membuat transisi terhadap lingkungan baru: c) mereka sendiri, keluarga mereka, keluarga lain, d) kelas sebagai komunitas, e) berinteraksi dengan orang dewasa baru, f) mengikuti rutinitas kelas (misalnya waktu makan, berbenah), g) mengidentifikasi bagian tubuh, perasaan-perasaan (bahasia, sedih, marah) dan kebutuhan (saya ingin mengecat, saya mau jus lagi), h) kontrol diri (menggunakan kata-kata, bukan tanganmu, meskipun mereka masih sulit mengingat peraturan), i) membantu diri sendiri (memakai jaket, mencuci tangan), j) mengikuti aturan satu langkah (letakkan lap di setiap bangku), k) berbagi dan bekerja sama.

Usia empat tahun penuh tenaga, antusiasme, dan rasa ingin tahu. Imajinasi mereka bekerja keras. Mereka penuh "mengapa" dan dapat mengadakan percakapan tingkat tinggi dengan mereka yang mempunyai pengetahuan yang sama. Mereka bermain dengan lebih koperatif bersama anak-anak lain. Menyukai fantasi dan melatih kontrol diri.

Dalam optimalisasi perkembangan bahasa anak, keluargamenjadikan anak untuk belajar: a) bermacam jenis buku-fiksi, non fiksi, puisi, b) bermain kata-kata dan lagu-lagu konyol, c) bercerita, d) menggambar untuk membuat ilustrasi cerita, atau bukan hanya melukis atau mewarnai, e) menggunakan boneka untuk mendramatiasi cerita, e) menggambar untuk ilustrasi cerita, bukan hanya melukis atau mewarnai, f) memperhatikan detail dalam cerita dan menambahkan detail dalam cerita mereka sendiri, g) meramalkan apa yang etrjadi dalam buku cerita dengan menggunakan ilustrasi sebagai panduan, h) menyanyi dan mengarang versi mereka sendiri i) mengidentifikasi huruf, menulis beberapa huruf mungkin nama mereka sendiri ataua nama orang lain, j) secara aktif, ikut serta dalam diskusi kelompok.

Dalam optimalisasi perkembangan fisik anak, keluarga membimbing anak untuk belajar: a) keterampilan motorik kasar. anak dapat mengayuh ayunan, memanjat tangga tali, meluncur dari tiang, meloncat, melompat, b) keterampilan motorik halus. Mereka dapat 
menggunakan guntig, kuas/krayon/spidol yang lebih kecil, merangkai manik-manik kecil, menyusun lego yang lebih kecil, mengancingkan baju.

Dalam optimalisasi perkembangan kognitif anak, keluarga mendampingi anak untuk belajar: a) memilih dan mengelompokkan bukan hanya dari warna dan ukuran, melainkan juga dengan kategori (misalnya semua boneka masuk ke wadah dan semua aksesoris dikotak lainnya), b) mengurutkan, dapat mengorganisasikan serangkaian kejadian dalam urutan sebelum dan sesudah, c) menghitung dari satu sampai dua puluh (atau lebih), d) sebab dan akibat (jika saya menuangkan terlalu banyak jus, akan tumpah) tetapi masih ada "pemikiran ajaib" (yang bisa sesederhana seperti percaya akan adanya peri gigi, tetapi juga dapat berupa "kalau saya berpikir buruk, pikiran itu akan terjadi"), e) perbandingan-lebih banyak/sedikit.

Dalam optimalisasi perkembangan sosial emosional anak, keluarga mendorong anak untuk belajar: a) bekerjasama dengan yang lain dalam mengerjakan sesuatu, bergiliran, membantu anak lain, empati: b) peran dalam keluarga dan tanggung jawab, c) menguasai rasa takut dan mengendalikan dorongan hati (tetapi masih sering ketakutan dan tidak selalu terkendali), d) kesamaan dan perbedaan sehubungan dengan jenis kelamin, ras, karakteristik fisik lainnya, e) membuat pilihan (saya ingin membuat dari balok, jadi saya tidak bisa melukis saat bermain bebas nanti), f) mereka sendiri, seperti kesukaan dan hobi mereka, g) mempunyai tujuan dalam aktivitas (saya akan memanjat puncak jungle gymdan meluncur turun dengan tiang "saya akan mengumpulkan mobil-mobilan dan kemudian membangun garansi dari balok-balok").

Usia Lima tahun ialah usia anak sudah mulai melakukan aktivitasnya kebanyakan di ruang lingkup sekolah. Usia lima tahun lebih terfokus dan terarah dibanding anak-anak prasekolah yang lebih muda. Mereka dapat bekerjasama dalam kelompok lebih besar untuk bermain permainan sederhana (sepak bola) dan mereka dapat memainkan sandiriwara dengan peran dan peraturan tertentu untuk semua peserta. Mereka kaya akan imajinasi, dan bahasa mereka ekspresif serta terperinci. Persahabatan adalah sangat penting dalam usia ini.

Dalam optimalisasi perkembangan bahasa anak usia lima tahun, keluarga membimbing anak untuk belajar: a) semua jenis buku dan mempunyai kesukaan pribadi pada subjek atau pengarang, b) mengenal semua huruf alfabet, mengeja nama mereka sendiri, kata-kata favorit, menghubungkanhuruf (konsonan) dengan bunyi, c) menggambar gambar representasional, d) menceritakan kembali cerita secara verbal, juga melalui gambar 
atau dramatisasi, e) meramalkan apa yang terjadi selanjutnya melalui gambar dan isi cerita, $\mathrm{f}$ ) ikut serta dalam diskusi kelas, termasuk menunggu giliran berbicara jika dipanggil.

Dalam optimalisasi perkembangan fisik anak, keluarga mendorong anak untuk mengembangkan: a) keterampilan motorik kasar. Koordinasi mata-tangan yang lebih kuat menghasilkan tendangan, tangkapan dan lemparan yang lebih baik. Dapat bermain permainan dan mengikuti peraturan sederhana tentang skor (misalnya sepak bola), b) keterampilan motorik halus. Genggaman tangan mereka lebih efektif: dapat menggunting mengikuti garis, memanipulasi penjepit atau peralatan lain (untuk sains), menggunakan kuas, krayon dan spidol yang lebih kecil.

Dalam optimalisasi perkembangan kognitif anak, keluarga membimbing anak untuk belajar tentang: a) memilih dan mengelompokkan menggunakan dua kategori (misalnya warna dan ukuran), b) tabel (misalnya, kelas mungkin membuat tabel untuk menggambar binatang peliharaan, berapa banyak anak-anak yang memelihara kucing, kleinci, burung,ikan, dll.c) menghitung dari satu sampai tiga puluh (atau lebih), c) menulis angka, e) perbandingan ukuran dan jumlah, f) konsep kalender, g) memperkirakan dan mengukur, h) menggunakan pemikiran dan keterampilan menyelesaikan masalah, i) penjelasan sederhana untuk fenomena sains.

Dalam optimalisasi perkembangan sosial/emosional anak, keluarga mendorong anak untuk belajar tentang: a) bertanggung jawab di kelas atau tugas tertentu di rumah (mendaur ulang, menggosongkan tempat sampah, membeir makan binatang peliharaan), b) mengatasi konflik dan menyelesaikan masalah mereka sendiri, c) kontrol diri lebih baik dan menyadari tingkah laku yang pantas, d) mengenali dan menyatakan emosi dan perasaan, e) menyatakan empati, f) individualitas dan mengenali kesamaan dan perbedaan tentang diri dan orang lain.

Beda usia anak beda pula cara mengoptimalkan psikologi perkembangannya. Keluarga yang merupakan manusia yang paling utama yang dijumpai anak seharusnya bisa memberikan stimulus anak dengan baik agar terciptanya psikologi perkembangan anak yang optimal.

\section{Penutup}

Kesibukan orang tua yang jarang dirumah menyebabkan anak tidak memiliki kedekatan dengan orang tua. Bentuk tanggung jawab sebagai keluarga dalam 
mengoptimalkan psikologi perkembangan anak harus di upayakan semaksimal mungkin. Dengan memlihara dan membesarkan anak, melindungi dan menjamin kesehatan anak, memberikan pendidikan yang layak, dan lain sebagainya merupakan keseharusnya yang harus dipenuhi oleh keluarga. Dengan mengoptimalkan psikologi perkembangan anak sesuai dengan usia anak sangat memudahkan keluarga dalam memaksimalkan perkembangannya. Jadi optimalisasi psikologi perkembangan anak sesuai dengan perkembangan usia anak yang sedang dialami, agar kedepannya anak bisa tumbuh dan berkembang dalam keluarga sesuai dengan harapan.

\section{Daftar Pustaka}

Ayun, Q. (2016). Dalam Membentuk Perkembangan Kepribadian Anak: Perspektif Psikologi Perkembangan Islam. Attarbiyah, 26, 91-118. https://doi.org/10.18326/attarbiyah.v26.91-118

Effendi, S., \& Dkk. (1995). Fungsi Keluarga dalam Meningkatkan Kualitas Sumber Daya manusia. Departemen Pendidikan dan Kebudayaan.

Gunadi, D. I. P. (2019). Peran Orang Tua dalam Optimalisasi Tumbuh Kembang Anak untuk Membangun Karakter Jujur. https://doi.org/10.31227/osf.io/zdt3g

H.B, E., \& A.C, E. (1958). A Comprehensive Dictonary Of Psychological and Sychoanalytic Term: A Guide The Usage. Longmans Green.

Hulukati, W. (2015). Peran Lingkungan Keluarga Terhadap Perkembangan Anak Wenny Hulukati. Musawa, 7(2), 265-282. https://media.neliti.com/media/publications/114008-ID-peran-lingkungan-keluargaterhadap-perke.pdf

Hurlock, E. B. (1980). Psikologi Perkembangan (Edisi Keli). Erlangga.

Idad, S. (2016). Psikologi Perkembangan Anak Usia Dini. PT Remaja Rosdaskarya.

Khoirunnisa, D. (2018). Pembelajaran E-Learning Perkembangan Anak di Jurusan Psikologi Online Learning Model for the Child Development Course in Psychology Department Riza Noviana Khoirunnisa, Damajanti Kusuma Dewi, Desi Nurwidawati Jurusan Psikologi Universitas Negeri Surabaya. Jurnal Psikologi Teori dan Terapan, 9(1), 62-76.

Novela, T. (2019). Dampak Peran Ayah Terhadap Perkembangan Emosional Anak Usia Dini. Raudhatul Athfal: Jurnal Pendidikan Islam Anak Usia Dini, 3(1), 16-29. https://doi.org/10.19109/ra.v3i1.3200

Paul, H., \& Dkk. (1988). Perkembangan dan Kepribadian Anak (keenam). Erlangga.

Peraturan Menteri Pendidikan dan Kebudayaan Nomor 146 Tahun 2014 Tentng Kurikulum 2013 Anak Usia Dini

Santrock, J. W. (2011). Educational Psychology (Edisi Keli). McGrawHill Companies.

Sugiyono. (2013). Metode Penelitian Pendidikan,(Pendekatan Kuantitatif, Kualitatif, dan R\&D).

Ulfa, M. (2020). Aulad: Journal on Early Childhood Peran Keluarga dalam Konsep Psikologi Perkembangan Anak Usia Dini. AULAD:Journal on Early Childhood, 
4798(February). https://doi.org/10.31004/aulad.v3i1.46

Undang-Undang Sistem Pendidikan Nasional Nomor 20 Tahun 2003

Undang-Undang Sistem Pendidikan Nasional Tahun 2013 